\title{
SPACE HEATING AND COOLING ENERGY DEMAND IN ENERGY EFFICIENT SINGLE- FAMILY HOUSE WITH MECHANICAL VENTILATION SYSTEM
}

\author{
Paolo Blecich, Igor Bonefačić, Igor Wolf
}

Original scientific paper

This paper investigates on the space heating and cooling energy demand as well as on the thermal comfort in energy efficient detached single-family houses with mechanical ventilation heat recovery system. The necessary energy calculations are based on a test reference year with one-hour-step weather data taken for the City of Rijeka which can be seen as an average location in Croatia in terms of weather conditions. The analysis consists of the comparison of three houses with different energy performance levels: a reference single-family house, a low-energy single-family house and a passive single-family house. As expected, the space heating energy demand is lowest in the passive house and highest in the reference house. The thermal comfort is best in the passive house and worst in the reference house. It is concluded that the mechanical ventilation heat recovery system is an indispensable part of the energy system in the passive house and that it can ensure significant energy savings in the low-energy house, too.

Keywords: energy efficient house; mechanical ventilation system; space cooling; space heating; thermal comfort

Potrebna energija za grijanje i hlađenje u energetski učinkovitoj obiteljskoj kući s mehaničkim sustavom ventilacije

Izvorni znanstveni članak

U ovom radu analizira se potrebna energija za grijanje i hlađenje prostora, kao i toplinski komfor u energetski učinkovitim samostojećim obiteljskim kućama sa mehaničkim sustavom ventilacije i rekuperacijom topline. Proračun toplinskih bilanci temelji se na satnim vrijednostima meteoroloških podataka iz referentne godine za područje Grada Rijeke u kojemu se meteorološki uvjeti mogu smatrati prosječnima za područje Hrvatske. Analiza obuhvaća usporedbu triju kuća s različitim razinama energetske učinkovitosti: referentna obiteljska kuća, niskoenergetska obiteljska kuća i pasivna obiteljska kuća. Očekivano, potrebna energija za grijanje je najmanja u pasivnoj kući, a najveća u referentnoj kući. Najbolji toplinski komfor postiže se u pasivnoj kući, a najgori u referentnoj kući. Zaključuje se da je rekuperatorom topline opremljeni mehanički sustav ventilacije nezaobilazan dio termotehničkog sustava pasivne kuće i da takav sustav može osigurati značajne uštede energije i u niskoenergetskoj kući.

Ključne riječi: energetski učinkovita kuća; grijanje prostora; hlađenje prostora; mehanički sustav ventilacije; toplinski komfor

\section{Introduction}

The energy consumption of buildings accounts for about $30 \%$ of the total energy consumption in Croatia [1]. It is estimated that space heating and space cooling represent $70 \%$ of the energy consumption of buildings while domestic hot water heating, cooking and electricity represent only $30 \%$ [2]. Consequently, the building sector offers numerous possibilities for significant energy savings. This can be done by tightening the codes that regulate the energy performance of newly built buildings or by performing energy retrofits on existing buildings.

Energy efficient buildings are being made more and more airtight and consequently less well ventilated. Since these buildings still need fresh air, mechanical ventilation is required $[3,4]$. The mechanical ventilation system with heat recovery (MVHR) supplies fresh air and ensures significant reductions of space heating and cooling energy consumption, both in residential [5] and office buildings [6]. The heat recovery unit consists of an air-to-air heat exchanger which transfers heat from exhaust indoor air to intake fresh air. Climate conditions, building air tightness and thermal insulation, heating and cooling set-point settings, humidity control, heat recovery efficiency and the chosen ventilation strategy affect significantly the performance of the MVHR system [7].

This paper analyses space heating and cooling energy demand as well as thermal comfort inside energy efficient single-family houses with MVHR system. The aim of this work is to determine the exact effects of the MVHR system on space heating and cooling demand as well as on ventilation electricity in energy efficient houses with low-energy house and passive house characteristics.
To this purpose, calculations based on hourly weather data are performed to determine annual space heating and cooling demand in energy efficient single-family houses. Dynamic simulation methods based on hourly values ensure more accurate results than quasi-steady-state methods based on average monthly values and empirical heat gain/loss utilization factors (ISO 13790:2008) [8].

\section{Input data for calculations}

\subsection{Weather data}

The weather data is represented by the typical meteorological year for the location of the City of Rijeka. This typical meteorological year contains hourly values of weather parameters such as air temperature and humidity, solar direct and diffuse radiation, wind speed and wind direction [9]. The climate of Rijeka can be considered to be about the average climate of Croatia. Rijeka has an average annual air temperature of $13,6{ }^{\circ} \mathrm{C}$, it has 2000 heating degree days and $1350 \mathrm{kWh} / \mathrm{m}^{2}$ of solar radiation annually [9]. On the other hand, the major part of the territory of Croatia, except mountain regions with rigid winters, has an average annual air temperature from 9,9 to $16,3^{\circ} \mathrm{C}$, from 1150 to 3100 heating degree days and from 1200 to $1550 \mathrm{kWh} / \mathrm{m}^{2}$ of solar radiation annually [10].

\subsection{Energy efficient single-family house}

The analysis compares three houses under different energy classes of the Croatian ranking system for energy performance of buildings. The first is a reference house (RH) with energy class $\mathrm{C}$, the second is a low-energy house (LH) with energy class $\mathrm{B}$ and the third is a passive 
house $(\mathrm{PH})$ with energy class $\mathrm{A}+$. The $\mathrm{LH}$ and the $\mathrm{PH}$ are equipped with MVHR systems which supply fresh air and reduce space heating demand. The three houses have equal topology but different energy systems, quality of thermal insulation and airtightness. Energy efficient houses ( $\mathrm{LH}$ and $\mathrm{PH}$ ) take advantage of better thermal insulation and airtightness which reduce the heating load per unit of floor area and thus make it possible to install low temperature heating sources (e.g. air-to-water heat pump) and efficient heating distribution systems such as underfloor heating (UFH) or MVHR. For example, the specific heating load should be smaller than $10 \mathrm{~W} / \mathrm{m}^{2}$ in order for the passive house to be heated exclusively with warm air distributed by the MVHR system [11].

Furthermore, energy efficient houses take advantage of large areas of highly efficient windows which collect solar radiation heat gains in winter. Nevertheless, energy efficient houses need protection from summer overheating which is usually provided by roof overhangs and awnings, window shades and night natural ventilation.

Tab. 1 lists the input data containing characteristics of the three analysed houses, necessary for calculations of space heating and space cooling energy demand.

Table 1 Input data for calculations: reference house (RH), low-energy house (LH) and passive house (PH)

\begin{tabular}{|c|c|c|c|c|}
\hline \multicolumn{2}{|c|}{ House energy rating } & $\mathrm{RH}$ & $\mathrm{LH}$ & $\mathrm{PH}$ \\
\hline \multicolumn{2}{|c|}{ Net floor area, $\mathrm{m}^{2}$} & 150 & 150 & 150 \\
\hline \multicolumn{2}{|c|}{ House shape factor } & 0,85 & 0,85 & 0,85 \\
\hline \multicolumn{2}{|c|}{ Air infiltration rate, $\mathrm{ACH}$} & 0,2 & 0,1 & 0,05 \\
\hline \multicolumn{2}{|c|}{ Floor $U$ value, $\mathrm{W} / \mathrm{m}^{2} \mathrm{~K}$} & 0,50 & 0,30 & 0,15 \\
\hline \multicolumn{2}{|c|}{ Wall $U$ value, $\mathrm{W} / \mathrm{m}^{2} \mathrm{~K}$} & 0,60 & 0,30 & 0,15 \\
\hline \multicolumn{2}{|c|}{ Roof $U$ value, $\mathrm{W} / \mathrm{m}^{2} \mathrm{~K}$} & 0,50 & 0,28 & 0,15 \\
\hline \multicolumn{2}{|c|}{ Windows $U$ value, $\mathrm{W} / \mathrm{m}^{2} \mathrm{~K}$} & 1,50 & 1,10 & 0,80 \\
\hline \multicolumn{2}{|c|}{ Thermal mass, $\mathrm{Wh} / \mathrm{m}^{2} \mathrm{~K}$} & 30 & 30 & 30 \\
\hline \multicolumn{2}{|c|}{ South-facing windows, $\mathrm{m}^{2}$} & 15 & 18 & 20 \\
\hline \multicolumn{2}{|c|}{ East-facing windows, $\mathrm{m}^{2}$} & 6 & 6 & 6 \\
\hline \multicolumn{2}{|c|}{ West-facing windows, $\mathrm{m}^{2}$} & 6 & 6 & 6 \\
\hline \multicolumn{2}{|c|}{ North-facing windows, $\mathrm{m}^{2}$} & 4 & 4 & 4 \\
\hline \multicolumn{2}{|c|}{ Glass transmittance, - } & 0,70 & 0,60 & 0,50 \\
\hline \multicolumn{2}{|c|}{ Indoor heat sources, $\mathrm{W} / \mathrm{m}^{2}$} & 3,0 & 2,5 & 2,0 \\
\hline \multicolumn{2}{|c|}{ Water vapour sources, $\mathrm{kg} / \mathrm{h}$} & 0,15 & 0,15 & 0,15 \\
\hline \multicolumn{2}{|c|}{ Space heating source } & Furnace & Heat & Heat \\
\hline \multicolumn{2}{|c|}{ Space cooling source } & AC unit & pump & pump \\
\hline \multicolumn{2}{|c|}{ Heating distribution system } & Radiators & UFH & MVHR \\
\hline \multicolumn{2}{|c|}{ Cooling distribution system } & AC unit & MVHR & MVHR \\
\hline \multicolumn{2}{|c|}{ Fresh air distribution } & Windows & MVHR & MVHR \\
\hline \multicolumn{2}{|c|}{ MVHR airflow rate, $\mathrm{m}^{3} / \mathrm{h}$} & 1 & 150 & 150 \\
\hline \multicolumn{2}{|c|}{ Heat recovery efficiency, - } & 1 & 0,80 & 0,80 \\
\hline \multirow{2}{*}{$\begin{array}{c}\text { Set-point } \\
\text { temperature, }{ }^{\circ} \mathrm{C}\end{array}$} & Heating & 20 & 20 & 20 \\
\hline & Cooling & 26 & 26 & 26 \\
\hline
\end{tabular}

\subsection{The MVHR system}

Energy efficient buildings are extremely airtight and well-insulated. Consequently, air infiltration does not exceed 0,1air changes per hour (ACH). The mechanical ventilation system supplies fresh air while the heat recovery unit reduces ventilation heat losses and increases the overall building energy efficiency. The MVHR system consists of air intake and air outlet units, a bypass duct for ventilation only that redirects fresh air before the heat recovery unit, an air heater, a humidifier and an air cooler downstream the heat recovery unit, one supply air ventilator and one exhaust air ventilator, ventilation ducts and a central control system, as shown in fig. 1 . The heat recovery unit is a flat plate air-to-air heat exchanger with thermal efficiency of 0,80 for both the MVHR in the LH and the MVHR in the PH. The air heater and the air cooler of the MVHR system are connected to an air-towater heat pump. The air-to-water heat pump is chosen here because it is one of the most common sources of heating and cooling energy for energy-efficient buildings. Nevertheless, the MVHR system may be coupled to other energy sources such as ground heat exchangers, groundto-water heat pumps, solar PV and solar thermal, if they would gain further energy and financial savings.

In the present analysis, only the $\mathrm{LH}$ and the $\mathrm{PH}$ are using the MVHR for fresh air distribution. Unlike the LH and $\mathrm{PH}$, fresh air enters randomly in the $\mathrm{RH}$, whenever occupants feel air quality has deteriorated and open the windows and doors. The natural air change rate depends on a number of factors: season and its climatic attributes, outdoor air quality and noise level, occupants' behaviour and habits. Natural air change rates between 0,3 and 0,8 $\mathrm{ACH}$ in winter and between 0,5 and 2,0 $\mathrm{ACH}$ in summer are commonly encountered in residential buildings [12]. In the present study, the natural air change rate in the $\mathrm{RH}$ is taken to be $0,5 \mathrm{ACH}$ from November 1 to March 31, 0,75 for both from April 1 to May 31 and from September 1 to October 31 and 1,5 ACH from June 1 to August 31.

In residential buildings with a MVHR system, the fresh airflow rate should be $9 \mathrm{~m}^{3} / \mathrm{h}$ per occupant and an additional $1,08 \mathrm{~m}^{3} / \mathrm{h}$ per $\mathrm{m}^{2}$ of net occupiable floor area [13]. This minimum airflow rate, in a detached two-storey single-family house with 5 occupants would result with $207 \mathrm{~m}^{3} / \mathrm{h}$ or $0,5 \mathrm{ACH}$, taken that the floor area is $150 \mathrm{~m}^{2}$ and the ceiling height $2,75 \mathrm{~m}$. However, since exterior walls are well-insulated, condensation is unlikely to occur in low-energy and passive buildings, thus an air change rate of 0,3 to $0,4 \mathrm{ACH}$ would still be acceptable and recommended [11].

In the $\mathrm{LH}$ and $\mathrm{PH}$, the air change rate supplied by the MVHR system is set to $0,36 \mathrm{ACH}$ which yields an airflow of $150 \mathrm{~m}^{3} / \mathrm{h}$, that is $1 \mathrm{~m}^{3} / \mathrm{h}$ per $\mathrm{m}^{2}$ of floor area. In order for the MVHR system to distribute the required space heating or cooling energy during peak load hours, the airflow rate or the temperature difference between supply air and indoor air may be increased. Excessive ventilation electricity consumption is prevented limiting the air change rate to a maximum of $0,8 \mathrm{ACH}$ in winter and 1,5 $\mathrm{ACH}$ in summer. The efficiency of ventilators is taken to be constant, regardless of airflow rate, and equal to 0,5 .

The electricity consumption for MVHR operation increases with the second power of the airflow rate. The referent value of electricity consumption is $0,45 \mathrm{~W} /\left(\mathrm{m}^{3} / \mathrm{h}\right)$ which is the maximum allowed consumption of ventilation electricity per unit of airflow in passive houses [11]. Whenever fresh air is thermally treated in the MVHR, ventilation electricity consumption is higher than that for ventilation only operating mode. In ventilation only mode, electricity consumption is lower because fresh air bypasses the thermal treatment units and thus the overall pressure drop in the MVHR system is reduced. 
It is clear from the above discussion that only highly efficient buildings (e.g. passive or nearly zero-energy buildings) may use MVHR systems for the supply of space heating since the heating load is small (usually below $10 \mathrm{~W} / \mathrm{m}^{2}$ ). A small heating load is required in order to supply the necessary space heating demand with low airflow rates, which ensure acceptable indoor thermal comfort and low ventilation electricity consumption. The cost of the MVHR system per unit of building floor area is estimated at $50 \mathrm{Eur} / \mathrm{m}^{2}$, whereas costs between 40 and $80 \mathrm{Eur} / \mathrm{m}^{2}$ have been reported [14]. In the winter period, humidity from exhaust air may condense and freeze in the heat recovery unit whenever intake air temperatures are below $-4{ }^{\circ} \mathrm{C}$. In this case, an anti-freeze protection switches on and preheats the intake air.

\section{Results and discussion \\ 3.1 Space heating and space cooling demand}

Fig. 2 shows the calculated daily space heating and space cooling energy demand in the reference house (RH), low-energy house ( $\mathrm{LH})$ and passive house $(\mathrm{PH})$. The annual space heating energy demand in the $\mathrm{RH}, \mathrm{LH}$ and $\mathrm{PH}$ is $87,6,28,6$ and $9,0 \mathrm{kWh} / \mathrm{m}^{2}$, respectively. The space cooling energy demand is $9,0,8,0$ and $8,2 \mathrm{kWh} / \mathrm{m}^{2}$ in the $\mathrm{RH}, \mathrm{LH}$ and $\mathrm{PH}$, respectively. The $\mathrm{PH}$ is the most well insulated and airtight house whereas space heating is needed for about 1000 hours throughout the year. In the LH space heating is turned on for about 2300 hours while in the RH for around 3500 hours.

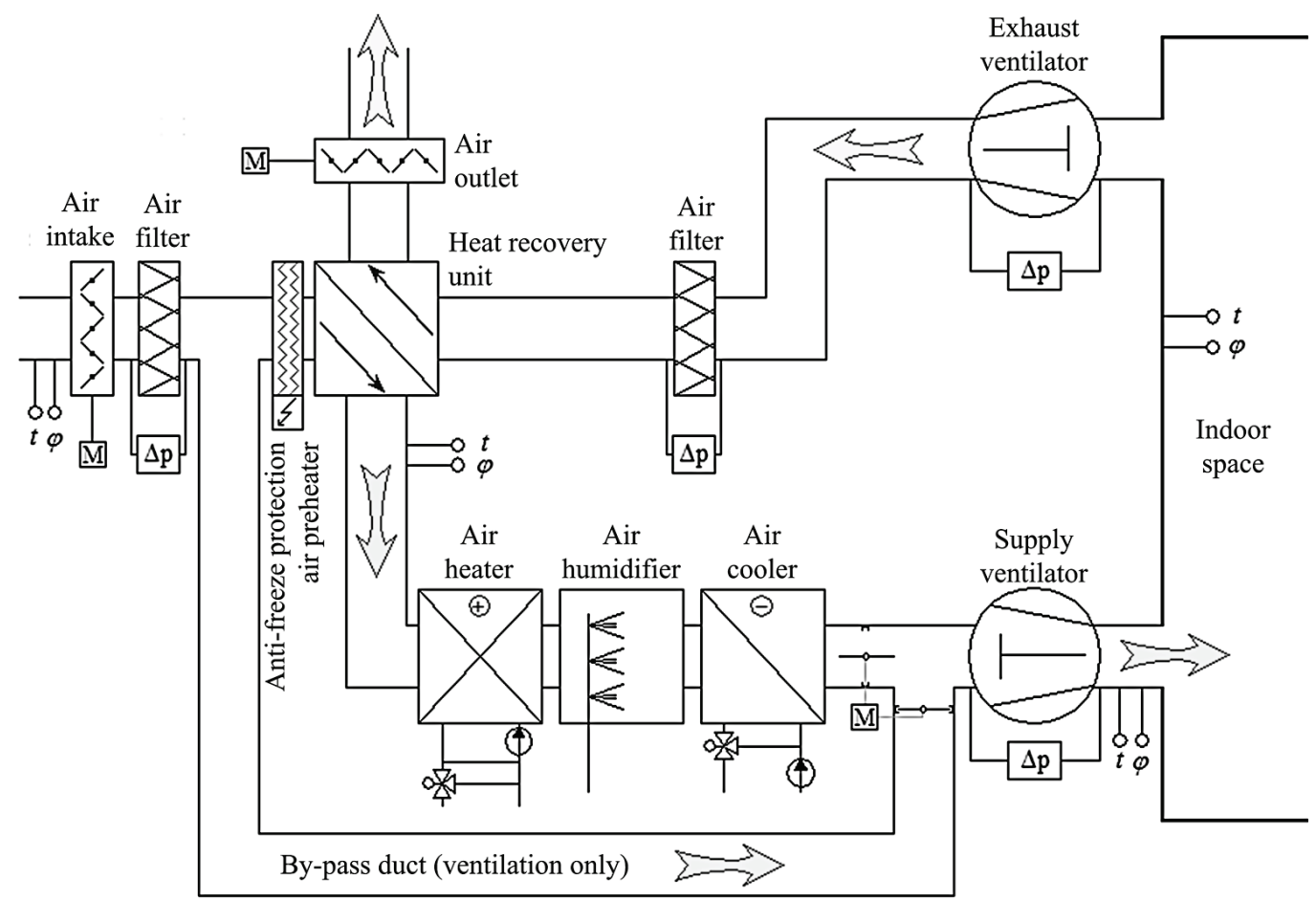

Figure 1Scheme of the mechanical ventilation heat recovery system (MVHR) with main components

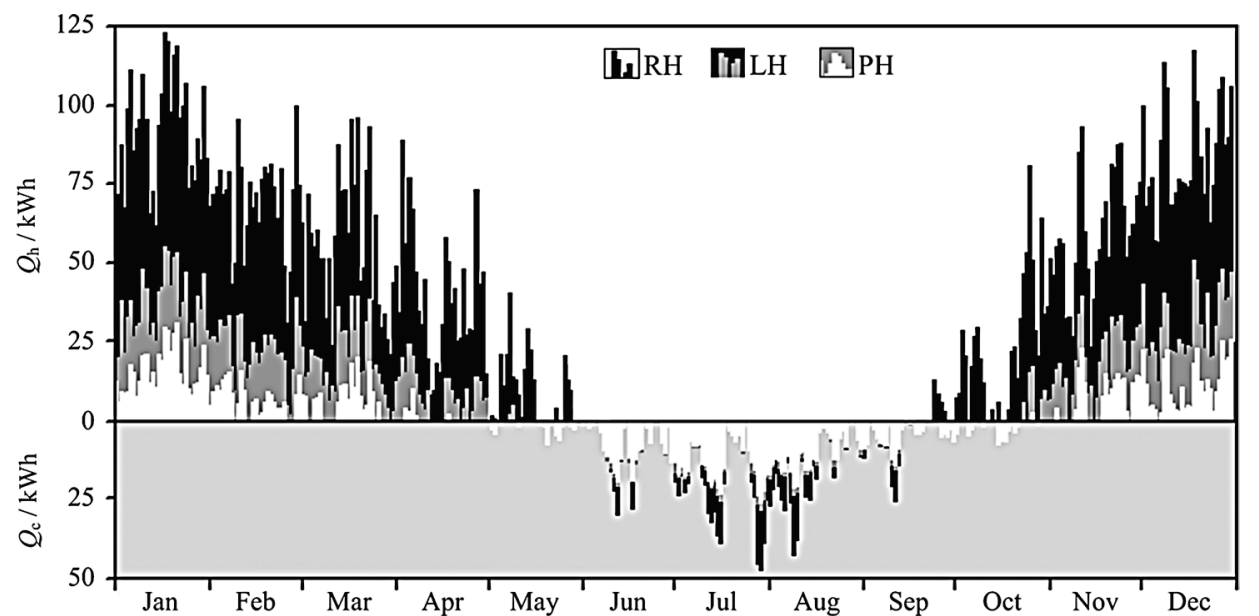

Figure 2 Daily space heating $\left(Q_{\mathrm{h}}\right)$ and cooling $\left(Q_{\mathrm{c}}\right)$ energy demand in the reference house $(\mathrm{RH})$, low-energyhouse (LH) and passive house (PH)

On the other hand, space cooling in the $\mathrm{PH}$ is turned on for as much as 950 hours. In the $\mathrm{LH}$ and $\mathrm{RH}$ space cooling is necessary for 770 and 550 hours, respectively. However, among the three houses, the RH has the largest annual space cooling energy demand, mainly because of higher heat gains due to air infiltration and solar radiation.

From the above, it is understood that well insulated and airtight buildings have shorter heating seasons but longer cooling seasons. Fig. 3 shows hourly values of 
supplied space heating and space cooling in the RH and in the PH. For an observed house in the analysis, the outside air temperature has a major influence on space heating and space cooling demand. Nevertheless, the space heating and space cooling demand is also influenced by other weather parameters such as heat gains by solar radiation, outside air humidity, wind speed and direction.

Fig. 3 shows hourly values of supplied space heating and cooling energy against outside air temperature. The balance point temperature is the outside air temperature at which heating or cooling are becoming necessary. It is seen that the heating balance point is $15^{\circ} \mathrm{C}$ in the $\mathrm{RH}$ and $12{ }^{\circ} \mathrm{C}$ in the $\mathrm{PH}$. On the other side, the cooling balance point temperature is $20^{\circ} \mathrm{C}$ in the $\mathrm{RH}$ and $17^{\circ} \mathrm{C}$ in the $\mathrm{PH}$. The balance point temperatures for the $\mathrm{LH}$ (not shown in Fig. 3) are $13,2{ }^{\circ} \mathrm{C}$ for heating and $18,3{ }^{\circ} \mathrm{C}$ for cooling.

From the above it can be understood that energy efficient houses postpone the start of the heating season but bring forward the start of the cooling season.

The maximum supplied space heating energy per unit area is $43 \mathrm{~W} / \mathrm{m}^{2}$ in the $\mathrm{RH}$ and $13 \mathrm{~W} / \mathrm{m}^{2}$ in the $\mathrm{PH}$. Not plotted in Fig. 3 is the maximum supplied space heating energy per unit area in the LH, which is $21 \mathrm{~W} / \mathrm{m}^{2}$.

The maximum space cooling energy per unit of floor area is $45 \mathrm{~W} / \mathrm{m}^{2}$ in the RH. In the $\mathrm{RH}$, the space cooling energy is supplied by AC units. Here, the supplied space cooling energy is considered to be equal to the space cooling demand which is not the case in the LH and $\mathrm{PH}$.

In the $\mathrm{LH}$ and $\mathrm{PH}$, instead by $\mathrm{AC}$ units, the required space cooling energy is supplied by MVHR systems. In these two houses, the supplied space cooling can be lower than the space cooling demand because of constraints on MVHR airflow rates and supply air temperatures. The supplied space cooling is limited to $12 \mathrm{~W} / \mathrm{m}^{2}$ because the maximum air change rate and the minimum supply air temperature are $1,5 \mathrm{ACH}$ and $18^{\circ} \mathrm{C}$, respectively.

The supplied space cooling energy in the MVHR could be increased by increasing the airflow rate or by increasing the temperature difference between supply air and indoor air. Both actions would negatively influence the overall energy balance and the thermal comfort in the $\mathrm{LH}$ and $\mathrm{PH}$. A too large temperature difference between supply air and indoor air affects negatively the indoor thermal comfort while a too large airflow rate increases excessively the ventilation electricity consumption of the MVHR system and the house energy consumption.

Yet again, large differences between supplied space cooling energy and space cooling demand would lead to higher indoor air temperatures which would worsen the indoor thermal comfort during the summer period.

In energy efficient houses, the space cooling energy demand can be maintained within acceptable ranges by implementing various passive cooling techniques. Roof overhangs, awnings and window shades significantly reduce heat gains from direct sun radiation. Night natural ventilation would remove the heat stored in the building massive walls and floors during the day [3]. Efficient electric appliances and lighting would reduce internal heat gains [15] and so on.
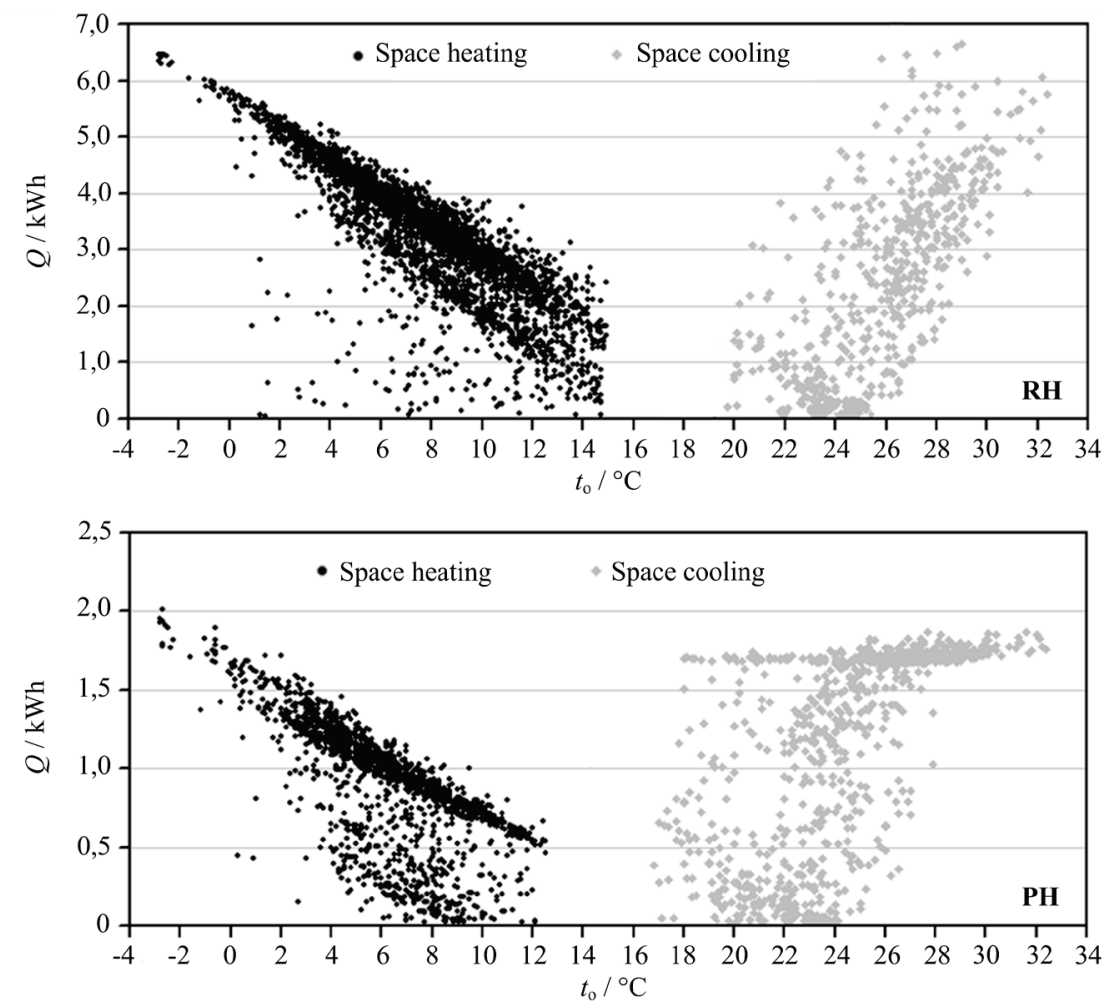

Figure 3 Calculated hourly values of space heating and cooling energy $(Q)$ in the RH and $\mathrm{PH}$ with regard to outside air temperature $\left(t_{0}\right)$

\subsection{Thermal comfort}

The thermal comfort in the three analysed houses is influenced by different environmental and personal factors such as air temperature and relative humidity, air speed, wall radiant temperature, occupant's clothing insulation and metabolic rate.

Different models and calculation procedures have been developed to determine the level of thermal comfort: the Predicted Mean Vote (PMV), the Predicted 
Percentage of Dissatisfied (PPD) as well as combined PMV/PPD models are the most commonly used methods [16].

In this work only the indoor air temperature and relative humidity are used to estimate the thermal comfort while other factors are disregarded. The thermal comfort is evaluated with three ratings:

1) favourable thermal comfort refers to temperatures from $19,5^{\circ} \mathrm{C}$ to $26,5^{\circ} \mathrm{C}$ and relative humidities from $35 \%$ to $70 \%$;

2) satisfying thermal comfort refers to air temperatures from $19{ }^{\circ} \mathrm{C}$ to $19,5{ }^{\circ} \mathrm{C}$ and from $26,5{ }^{\circ} \mathrm{C}$ to $27,5{ }^{\circ} \mathrm{C}$, and to relative humidities from $30 \%$ to $35 \%$ and from $70 \%$ to $75 \%$;

3) unacceptable thermal comfort refers to temperatures under $19{ }^{\circ} \mathrm{C}$ and above $27,5{ }^{\circ} \mathrm{C}$, and to relative humidities under $30 \%$ and above $75 \%$.

Fig. 4 shows the calculated hourly values of thermal comfort in terms of indoor air temperature and relative humidity achieved in the RH and in the PH. It can be seen that the overall thermal comfort in the $\mathrm{PH}$ is better than in the RH. This is a result of the MVHR system as well as of better thermal insulation and airtightness in the $\mathrm{PH}$.

In the $\mathrm{PH}$ air relative humidity is favourable or satisfying for greater part of the year. This is because the MVHR system is equipped with a humidifier which adds water vapour to fresh intake air in the winter period. Also, the MVHR system has an air cooler which removes excess humidity from intake air in the summer period. On the other hand, air humidity is not controlled in the $\mathrm{RH}$ because fresh air enters the RH by infiltration and through windows. Having no MVHR system which could adjust air humidity to acceptable values, air humidity in the RH is under unacceptable thermal comfort rating for a large number of hours.

Air temperature in the $\mathrm{PH}$ is controlled by the MVHR system which supplies the entire space heating and space cooling demand. Even though the space cooling output supplied by the MVHR system is limited to $12 \mathrm{~W} / \mathrm{m}^{2}$, the air temperature in the $\mathrm{PH}$ does not exceed $27^{\circ} \mathrm{C}$ which is still under satisfying thermal comfort rating. The overall thermal comfort in the $\mathrm{PH}$ and in the $\mathrm{LH}$ is better than the overall thermal comfort in the $\mathrm{RH}$.
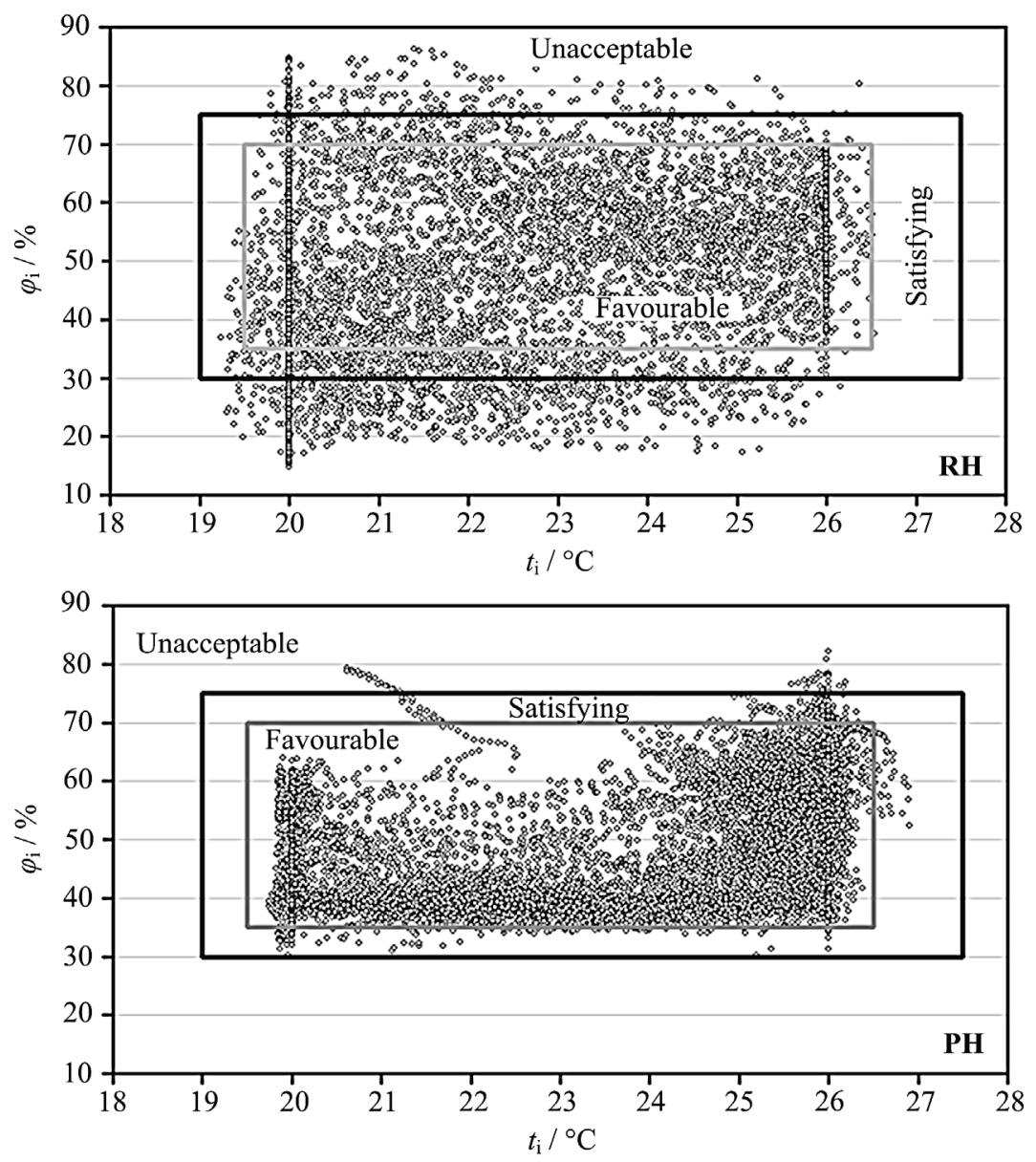

Figure 4 Calculated hourly values of thermal comfort in the RH and PH, in terms of indoor air relative humidity $\left(\varphi_{\mathrm{i}}\right)$ and air temperature $\left(t_{\mathrm{i}}\right)$

Tab. 2 lists the number of hours throughout the test reference year for which thermal comfort in the $\mathrm{RH}, \mathrm{LH}$ and $\mathrm{PH}$ is under favourable, satisfying and unacceptable rating.

The thermal comfort of the $\mathrm{LH}$ and $\mathrm{PH}$ is significantly better than the thermal comfort of the RH. This is because of improved thermal insulation and airtight envelope that dampen the oscillations of outside air temperature and humidity. Also, the MVHR systems of the $\mathrm{LH}$ and $\mathrm{PH}$ are capable of regulating air temperature and humidity more successfully than the heating/cooling system of the RH.

The RH has a total of 1469 hours with unacceptable thermal comfort, mainly because of too dry or too humid indoor air. The $\mathrm{LH}$ and the $\mathrm{PH}$ also have a certain number of hours with unacceptable thermal comfort rating: 78 and 
47, again because of too humid indoor air. These hours occur on warm and rainy days during spring and fall when outside air temperature is still too low to operate the MVHR system in cooling mode. Operating the MVHR system in drying mode or adding a dehumidifier would be the solution to this problem. The analysis of the MVHR system operating in drying mode is not presented here as it goes beyond the scope of this paper.

Table 2 Number of year-round hours of favourable, satisfying and unacceptable thermal comfort in the $\mathrm{RH}, \mathrm{LH}$ and $\mathrm{PH}$

\begin{tabular}{|c|c|c|c|c|}
\hline \multicolumn{2}{|c|}{ House energy rating } & $\mathrm{RH}$ & $\mathrm{LH}$ & $\mathrm{PH}$ \\
\hline \multirow{3}{*}{$\begin{array}{c}\text { Thermal } \\
\text { comfort } \\
\text { rating }\end{array}$} & Favourable & 6005 & 8310 & 8409 \\
\hline & Satisfying & 1286 & 372 & 304 \\
\hline & Unacceptable & 1469 & 78 & 47 \\
\hline \multicolumn{2}{|c|}{ Total number of hours } & 8760 & 8760 & 8760 \\
\hline
\end{tabular}

The temperature-humidity diagram for the RH (Fig. 4) shows that a significant number of hours have air relative humidity under $30 \%$. These hours are too dry and result with unacceptable thermal comfort rating. From here it can be concluded that MVHR systems of energy efficient buildings need humidifiers for the winter period.

The Passive House Institute (Darmstadt, Germany) recommends that MVHR systems do not need humidifiers for the control of indoor air quality in the winter period. According to the Institute, airflow rates can be decreased, within acceptable limits, in order to increase air humidity, as moisture from internal sources is less diluted.

Table 3 Rating of thermal comfort in $\mathrm{LH}$ and $\mathrm{PH}$ without humidifiers in MVHR systems

\begin{tabular}{|c|l|c|c|}
\hline \multicolumn{2}{|c|}{ House energy rating } & LH & PH \\
\hline \multirow{3}{*}{$\begin{array}{c}\text { Thermal comfort } \\
\text { rating }\end{array}$} & Favourable & 6667 & 6609 \\
\cline { 2 - 4 } & Satisfying & 1223 & 1164 \\
\cline { 2 - 4 } & Unacceptable & 870 & 987 \\
\hline \multicolumn{2}{|c|}{ Total number of hours } & 8760 & 8760 \\
\hline
\end{tabular}

However, the present analysis proves that reduction of airflow rate and internal sources of moisture do not guarantee satisfactory levels of air relative humidity. In the present calculations, internal sources of moisture were set to $0,25 \mathrm{~kg} / \mathrm{h}$ and the minimum airflow rate is $150 \mathrm{~m}^{3} / \mathrm{h}$ on a floor area of $150 \mathrm{~m}^{2}$. Now, if the air humidifier is removed from the MVHR system, the thermal comfort in the $\mathrm{LH}$ and $\mathrm{PH}$ deteriorates. Tab. 3 lists the number of hours with favourable, satisfying and unacceptable thermal comfort in the $\mathrm{LH}$ and $\mathrm{PH}$ in which the MVHR systems have no humidifiers.

Removing the humidifier from the MVHR system reduces the number of hours with favourable thermal comfort by about $20 \%$ in both the LH and the PH. Now, the thermal comfort is unacceptable for $10 \%$ of the year in the $\mathrm{LH}$ and for $11 \%$ of the year in the PH. These numbers are still better than the ones for the RH where thermal comfort is unacceptable for $17 \%$ of the year.

On the other side, the removal of the humidifier from the MVHR system results into reductions of space heating energy and ventilation electricity consumption. Space heating energy consumption is reduced by $1 \mathrm{kWh} / \mathrm{m}^{2}$ a because no heat is required to evaporate the added water in the humidifier. Ventilation electricity consumption is also slightly reduced because of the lower air pressure drop in the MVHR system.

\subsection{Performance of the MVHR system}

The MVHR system consumes electricity, primarily for running the supply ventilator and the exhaust ventilator. The relation between ventilation electricity consumption and airflow rate is given in Fig. 1. The total annual ventilation electricity consumption is expressed per unit of floor area. Ventilation accounts for $5 \%$ to 10 $\%$ of the primary energy consumption in energy efficient buildings [17]. One of the requirements of the Passive House Standard is the annual primary energy consumption which must not exceed $120 \mathrm{kWh} / \mathrm{m}^{2} \mathrm{a}$ in a passive house [11].

In the present analysis, the total annual ventilation electricity consumption is calculated at $7,0 \mathrm{kWh} / \mathrm{m}^{2} \mathrm{a}$ in the $\mathrm{LH}$ and $8,8 \mathrm{kWh} / \mathrm{m}^{2} \mathrm{a}$ in the $\mathrm{PH}$. Ventilation for the distribution of space cooling presents a major burden to the total electricity consumption of the MVHR system. Space cooling requires larger airflow rates than space heating because the maximum temperature difference between supply and indoor air is only $8{ }^{\circ} \mathrm{C}$ for cooling while it is $20^{\circ} \mathrm{C}$ for heating. In the period from April 16 to October 15 , which is dominated by space cooling, the total ventilation electricity consumption is $6,3 \mathrm{kWh} / \mathrm{m}^{2}$ in the $\mathrm{LH}$ and $7,5 \mathrm{kWh} / \mathrm{m}^{2}$ in the $\mathrm{PH}$, respectively.

Seasonal bypassing is used in the MVHR systems of the LH and PH. The heat recovery (HR) unit is employed only during the heating season while it is bypassed in the cooling season. The HR unit would have only a small effect on space cooling energy consumption because of small temperature differences between outside and indoor air. For example, the maximum outside air temperature in the typical meteorological year for Rijeka is $32,4{ }^{\circ} \mathrm{C}$.

Fig. 5 shows the number of hours per day during which the HR unit is employed. The total annual number of working hours of the HR unit is 4358 in the LH and 3767 in the PH. This difference in working hours is caused by the higher level of insulation and air-tightness in the PH. It can be seen that the HR unit operates all day or for greater part in the period from November to March but only occasionally in April, May, September and October.

The MVHR system of the LH operates with constant airflow rate of $150 \mathrm{~m}^{3} / \mathrm{h}(0,36 \mathrm{ACH})$ in the winter period. This is because the MVHR system supplies only the minimum amount of fresh air while space heating energy is supplied by the UFH system. However, in the summer period, the average per day airflow rate is increased to up to $400 \mathrm{~m}^{3} / \mathrm{h}(1,0 \mathrm{ACH})$ in order to supply the necessary space cooling energy. The MVHR system of the PH supplies both fresh air and space heating energy in the winter period. The airflow rate increases above $150 \mathrm{~m}^{3} / \mathrm{h}$ whenever space heating demand is increased.

The MVHR system is an indispensable part of the energy system of an energy efficient building. Tab. 4 shows the increase of space heating and space cooling energy demand if the MVHR system would be removed from the $\mathrm{LH}$ and the $\mathrm{PH}$. Space heating and space cooling energy demand increases significantly in the absence of a MVHR system as fresh air supply is not controlled. On 
the other side, the MVHR system needs electricity, mainly for running the two ventilators.

Table 4 Comparison of energy demand with and without MVHR system in the $\mathrm{LH}$ and $\mathrm{PH}$

\begin{tabular}{|c|l|c|c|c|c|}
\hline \multicolumn{2}{|c|}{ House energy rating } & \multicolumn{2}{c|}{ LH } & \multicolumn{2}{c|}{ PH } \\
\hline \multicolumn{2}{|c|}{ MVHR system } & Yes & No & Yes & No \\
\hline \multirow{2}{*}{$\begin{array}{c}\text { Energy } \\
\text { demand, } \\
\mathrm{kWh} / \mathrm{m}^{2} \mathrm{a}\end{array}$} & Space heating & 28,6 & 50,8 & 9,0 & 30,4 \\
\cline { 2 - 6 } & Space cooling & 8,0 & 12,4 & 8,2 & 12,7 \\
\cline { 2 - 6 } & Ventilation & 7,0 & 0 & 8,8 & 0 \\
\hline \multicolumn{2}{|c|}{$\begin{array}{c}\text { Total primary energy } \\
\text { consumption, } \mathrm{kWh} / \mathrm{m}^{2} \mathrm{a}\end{array}$} & 54,1 & 63,2 & 39,2 & 43,1 \\
\hline
\end{tabular}

The MVHR system reduces the total primary energy consumption in the analysed $\mathrm{LH}$ and $\mathrm{PH}$. This is not a general conclusion, though, as the MVHR can increase primary energy consumption in energy efficient buildings, depending on the chosen ventilation strategy $[14,17]$.

The primary energy conversion factors are: 1,0 for space heating and space (source: heat pump) and 2,5 for electricity (source: power plants). The MVHR reduces the total primary energy consumption by $15 \%$ in the $\mathrm{LH}$ and by $10 \%$ in the $\mathrm{PH}$. Since the primary energy reduction is only $10 \div 15 \%$, it could be argued that the MVHR system is not going to be repaid through achievable energy savings.

The payback period of MVHR systems depends on the investment cost, the energy price, the ventilation strategy, the heat recovery efficiency and so on. Payback periods of around 10 years are reported for MVHR systems [3]. After all, the passive house ( $\mathrm{PH})$ is not a passive house without the MVHR system because the space heating demand is required to be less than 15 $\mathrm{kWh} / \mathrm{m}^{2} \mathrm{a}$.

Table 5 Space cooling and ventilation electricity demand for two night natural ventilation strategies in the $\mathrm{LH}$ and the $\mathrm{PH}$

\begin{tabular}{|c|c|c|c|c|c|}
\hline \multicolumn{2}{|c|}{ House energy rating } & \multicolumn{2}{c|}{ LH } & \multicolumn{2}{c|}{ PH } \\
\hline \multicolumn{2}{|c|}{ Ventilation strategy } & VS1 & VS2 & VS1 & VS2 \\
\hline $\begin{array}{c}\text { Energy } \\
\text { demand, } \\
\mathrm{kWh} / \mathrm{m}^{2} \mathrm{a}\end{array}$ & Space cooling & 6,8 & 5,8 & 7,0 & 5,7 \\
\cline { 2 - 6 } & Ventilation & 6,1 & 5,5 & 7,8 & 6,5 \\
\hline
\end{tabular}

Space cooling and ventilation electricity can be further reduced employing night natural ventilation to remove the heat stored in the house during the day. Two ventilation strategies with different air change rates are analysed here: the first with 1,5 ACH (VS1) and the second with 3,0 ACH (VS2). In both strategies, night ventilation is used from 22.00 to 5.00 hours every night in the period from June 1 to August 31 . VS1 reduces space cooling by $15 \%$ and ventilation electricity by about $12 \%$. VS2 reduces space cooling by about $30 \%$ and ventilation electricity by about $25 \%$ in both the $\mathrm{LH}$ and the $\mathrm{PH}$, as given in Tab. 5 .

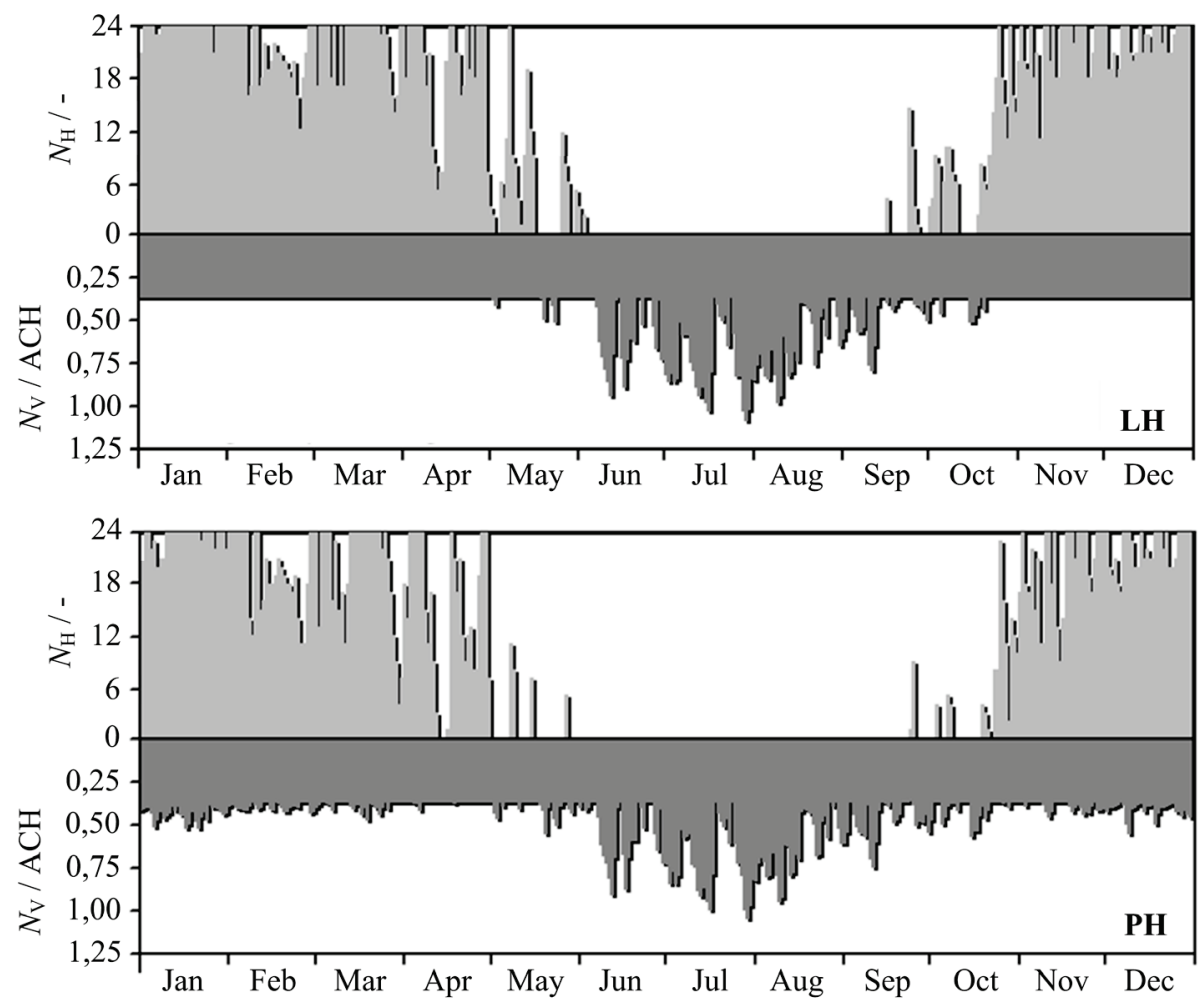

Figure 5 Operating hours of heat recovery unit $\left(N_{\mathrm{H}}\right)$ in the MVHR system and average daily air change rates $\left(N_{\mathrm{V}}\right)$ in the LH and PH

\section{Conclusion}

This paper investigated on space heating and space cooling energy demand as well as on thermal comfort in energy efficient houses with mechanical ventilation heat recovery (MVHR) system. The analysis compares three houses with different energy classes: a reference house
(RH) with energy class C, a low-energy house (LH) with class $\mathrm{B}$ and a passive house $(\mathrm{PH})$ with class $\mathrm{A}+$. The $\mathrm{LH}$ and the $\mathrm{PH}$ are equipped with MVHR systems.

The calculated space heating demand is 87,6 $\mathrm{kWh} / \mathrm{m}^{2} \mathrm{a}$ in the $\mathrm{RH}, 28,6 \mathrm{kWh} / \mathrm{m}^{2} \mathrm{a}$ in the $\mathrm{LH}$ and 9,0 $\mathrm{kWh} / \mathrm{m}^{2} \mathrm{a}$ in the $\mathrm{PH}$. It is seen that the heating season starts later while the cooling season starts earlier in 
energy efficient buildings. Among the three houses, thermal comfort is best in the $\mathrm{PH}$ and worst in the RH. The MVHR system has a very important role in energy efficient buildings. The MVHR system supplies fresh air, reduces significantly space heating and space cooling demand while it ensures improved indoor thermal comfort.

It is seen that a building cannot comply passive house standards without a MVHR system. This system reduces space heating demand from 30,4 to $9,0 \mathrm{kWh} / \mathrm{m}^{2} \mathrm{a}$ in an analysed single-family passive house. The MVHR system can be equipped with an air humidifier to ensure better control of indoor air humidity. Depending on the chosen ventilation strategy, ventilation electricity consumption is between 5 and $9 \mathrm{kWh} / \mathrm{m}^{2}$ a for efficient buildings with MVHR systems. Night natural ventilation during summer reduces space cooling demand and ventilation electricity.

The fast growing prices of energy and energy security concerns are forcing regulations for energy performance of buildings to become stricter in the EU. The directive 2010/31/EU requires that all new buildings are nearlyzero energy buildings by the end of 2020 [18]. This means extremely well-insulated and airtight buildings which will use on-site energy from renewable sources.

In Croatia, the regulation on energy performance of buildings tightened in 2014 . For example, the maximum allowed space heating demand of $90 \mathrm{kWh} / \mathrm{m}^{2} \mathrm{a}$ [19] was lowered to about $40 \mathrm{kWh} / \mathrm{m}^{2}$ a [20] for a single-family house at the location of the City of Rijeka.

According to the new regulation, a nearly-zero energy single-family house has an annual primary energy consumption (including heating cooling, ventilation and hot water preparation) from 30 to $40 \mathrm{kWh} / \mathrm{m}^{2} \mathrm{a}$, depending on meteorological conditions at the location [20]. Surely, the mechanical ventilation system with heat recovery is going to be an indispensable part of the energy system of future nearly-zero energy buildings.

\section{References}

[1] Annual Energy Report - Energy in Croatia 2012. Ministry of Economy, Republic of Croatia, Zagreb, 2013.

[2] Energy Efficiency and Energy Consumption in Household Sector. European Energy Agency. 2012. http://www.eea.europa.eu/data-and-maps/indicators/ Energy-efficiency-and-energy-consumption-5/assessment (01.01.2015)

[3] Mumovic, D.; Santamouris, M. A Handbook of Sustainable Building Design \& Engineering: An Integrated Approach to Energy, Health and Operational Performance. London: Earthscan, 2009

[4] Homod, R. Z.; Sahari, K. S. M. Energy Savings by Smart Utilization of Mechanical and Natural Ventilation for Hybrid Residential Building Model in Passive Climate. // Energy and Buildings, 60, (2013), pp. 310-329. DOl: 10.1016/j.enbuild.2012.10.034

[5] Fouih, Y.; Stabat, P.; Riviere, P.; Hoang, P.; Archambault, V. Adequacy of Air-to-Air Heat Recovery Ventilation System Applied in Low Energy Buildings. // Energy and Buildings, 54, (2012), pp. 29-39. DOl: 10.1016/j.enbuild.2012.08.008
[6] Gunner, A.; Hultmark, G.; Vorre, A.; Afshari, A.; Bergsoe, N. C. Energy-saving Potential of a Novel Ventilation System with Decentralised Fans in an Office Building. // Energy and Buildings, 84, (2014), pp. 360-366. DOl: 10.1016/j.enbuild.2014.08.029

[7] Santos, H. R. R.; Leal, V. M. S. Energy vs. Ventilation Rate in Buildings: A Comprehensive Scenario-Based Assessment in the European Context. // Energy and Buildings, 54, (2012), pp. 111-121. DOl: 10.1016/j.enbuild.2012.07.040

[8] ISO 13790:2008. Energy Performance of Buildings Calculation of Energy for Space Heating and Cooling. https://www.iso.org/obp/ui/\#iso:std:41974:en. (01.01.2015)

[9] Viličić, I. Investigation on the Effects of Meteorological Parameters on Heating and Cooling of Buildings in Littoral Croatia, Doctoral Dissertation, (in Croatian), Faculty of Engineering, University of Rijeka, 1992.

[10] Official Gazette of Croatia (NN 110/08). Meteorological parameters, location and altitude for weather stations. 2008.

[11] Feist, W. Certified Passive House - Certification Criteria for Residential Passive House Building, Passive House Institute, Darmstadt, Germany, 2013.

[12] Yamamoto, N.; Shendell, D. G.; Winer, A. M.; Zhang, J. Residential Air Exchange Rates in Three Major US Metropolitan Areas: Results from the Relationship among Indoor, Outdoor, and Personal Air Study 1999-2001. Indoor Air, 20, (2010), pp. 85-90. DOI: 10.1111/j.16000668.2009.00622.x

[13] ANSI/ASHRAE Standard 62.1-2010, Ventilation for Acceptable Indoor Air Quality, Atlanta, GA, USA, 2010.

[14] Blecich, P.; Franković, M., Kristl, Ž. Energy Retrofit of the Krsan Castle: from Sustainable to Responsible Design - a Case Study // Energy and Buildings, 122, (2016), pp. 23-33. DOI: 10.1016/j.enbuild.2016.04.011

[15] Franković, D.; Pavković, B.; Bupić, M. Consequences of Energy Efficiency Measures Implementation to Buildings' Electrical Systems. // Technical Gazette. 18, (2011), pp. 113.

[16] Wolf, I. Experimental Analysis of Thermal Comfort in an Air Conditioned Open Office Space. // Strojarstvo, 52, 6, (2010), pp. 651-663.

[17] Dodoo, A.; Gustavsson, L.; Sathre, R. Primary Energy Implications of Ventilation Heat Recovery in Residential Buildings. // Energy and Buildings. 43, (2011), pp. 15661572. DOI: 10.1016/j.enbuild.2011.02.019

[18] Official Journal of the EU: Directive 2010/31/EU on the Energy Performance of Buildings, L153, pp. 13-35, 2010.

[19] Official Gazette of Croatia (NN 110/08). Regulation on rational energy use and building thermal insulation. 2008.

[20] Official Gazette of Croatia (NN 97/14). Regulation on rational energy use and building thermal insulation. 2014.

\section{Authors' addresses}

dr. sc. Paolo Blecich, dipl. ing.

Faculty of Engineering, University of Rijeka Vukovarska 58, 51000 Rijeka paolo.blecich@riteh.hr

dr. sc. Igor Bonefačić, dipl. ing.

Faculty of Engineering, University of Rijeka Vukovarska 58, 51000 Rijeka

igor.bonefacic@riteh.hr

dr. sc. Igor Wolf, dipl. ing

Faculty of Engineering, University of Rijeka Vukovarska 58, 51000 Rijeka igor.wolf@riteh.hr 